Konya Mühendislik Bilimleri Dergisi, c. 9, Özel Sayı, 107-123, 2021

Konya Journal of Engineering Sciences, v. 9, Special Issue, 107-123, 2021

ISSN: 2667-8055 (Electronic)

DOI: $10.36306 /$ konjes.982692

\title{
MESOPOROUS ALUMINOSILICATE SUPPORTED CATALYSTS IN ALTERNATIVE FUEL HYDROGEN PRODUCTION
}

\author{
${ }^{1}$ Saleh Ahmat IBRAHIM ${ }^{(D)}$, ${ }^{2}$ Emine EKİNCI ${ }^{(D)}$, ${ }^{3}$ Birce PEKMEZCI KARAMAN ${ }^{(D)}$, ${ }^{4}$ Nuray OKTAR \\ Gazi University Chemical Engineering Department, Ankara, TURKEY \\ ${ }^{1}$ ahmatsaleh35@gmail.com, ${ }^{2}$ eminekaya@gazi.edu.tr, ${ }^{3}$ bircepekmezci@gazi.edu.tr, ${ }^{4}$ nurayoktar@gazi.edu.tr
}

\section{Geliş/Received: 15.08.2021; Kabul/Accepted in Revised Form: 26.11.2021)}

\begin{abstract}
In the present study, Ni-containing mesoporous aluminosilicate $\left(\mathrm{Al}_{2}\left(\mathrm{SiO}_{2}\right)_{3}\right)$ supported catalysts, which are resistant to carbon formation, were developed for hydrogen production from acetic acid. Commercial aluminosilicate $\left(\mathrm{Al}_{2}\left(\mathrm{SiO}_{2}\right)_{3}\right)$ was used as catalyst support. Furthermore, to improve the catalyst stability, $\mathrm{Mg}$, La, Ce, Ca, Ru metals, and $\mathrm{Ni}$ ( $5 \%$ by mass) were incorporated by the wet impregnation method into the catalyst supports' structure. The synthesized catalysts were characterized to define their physical and chemical properties. $\mathrm{N}_{2}$ adsorption-desorption results reveal that the resulting isotherm behavior of all the prepared catalysts is consistent with type IV isotherm with plate-like wall structures. The catalytic activity test of the prepared catalysts was investigated at a reaction temperature of $750 \mathrm{C}$ and a feed molar ratio of $1 / 2.5\left(\mathrm{AA} / \mathrm{H}_{2} \mathrm{O}\right)$ in a packed bed continuous reactor system. Activity test results showed that catalyst composition has profound effects on product distribution. Hydrogen-rich syngas was produced over $5 \mathrm{Ni}$ $3 \mathrm{Ru} @ \mathrm{Al}_{2}\left(\mathrm{SiO}_{2}\right)_{3}$ and $5 \mathrm{Ni}-3 \mathrm{CeO}_{2} @ \mathrm{Al}_{2}\left(\mathrm{SiO}_{2}\right)_{3}$ (about \% 44 and \% 46, respectively) catalysts. However, the addition of $\mathrm{MgO}$ over the $5 \mathrm{Ni} @ \mathrm{Al}_{2}\left(\mathrm{SiO}_{2}\right)_{3}$ catalyst strongly influenced the selectivity of hydrogen. Syngas, which contains an equimolar amount of $\mathrm{H}_{2}$, and $\mathrm{CO}$ is a quite important feedstock for the Fischer-Tropsch process (about $35 \%$ each), was obtained with the $5 \mathrm{Ni}-3 \mathrm{MgO} @ \mathrm{Al}_{2}\left(\mathrm{SiO}_{2}\right)_{3}$ catalyst.
\end{abstract}

Keywords: Nickel, Commercial aluminosilicate, Acetic acid, Steam reforming, Hydrogen

\section{Alternatif Yakıt Hidrojen Üretiminde Mezogözenekli Alüminosilikat Destekli Katalizörler}

ÖZ: Bu çalışma kapsamında asetik asitten hidrojen üretimi için karbon oluşumuna karşı dirençli Ni içerikli mezogözenekli alüminosilikat $\left(\mathrm{Al}_{2}\left(\mathrm{SiO}_{2}\right)_{3}\right)$ destekli katalizörler geliştirilmiştir. Mezogözenekli ticari alüminosilikat $\left(\mathrm{Al}_{2}\left(\mathrm{SiO}_{2}\right)_{3}\right)$ katalizör destek malzemesi olarak kullanılmıştır. Ayrıca, ticari alüminosilikat destek malzemesinin yapısına hidrojen seçiciliğinin arttırılması için nikelin yanısıra $\mathrm{Mg}, \mathrm{La}, \mathrm{Ce}, \mathrm{Ca}$ ve $\mathrm{Ru}$ metalleri (kütlece \% 5) 1slak emdirme yöntemi ile yüklenmiştir. Sentezlenen katalizörlerin bazı fiziksel ve kimyasal özelliklerini belirlenmesi için karakterizasyon analizleri gerçekleştirilmiştir. Mezogözenekli $\mathrm{Al}_{2}\left(\mathrm{SiO}_{2}\right)_{3}$ malzemelerinin $\mathrm{N}_{2}$ adsorpsiyon-desorpsiyon analizi sonucu elde edilen izotermleri Tip IV izotermi ile uyumlu olup malzemelerin levha gibi yapıda olduğu saptanmıştır. Hazırlanan katalizörlerin katalitik aktivite testleri sürekli akışlı dolgulu reaktör sisteminde $750 \mathrm{C}$ reaksiyon sıcaklığında ve 1/2.5 (AA/ $\left.\mathrm{H}_{2} \mathrm{O}\right)$ besleme molar oranında yürütülmüştür. Aktivite test çalışmaları sonucunda katalizör içeriğinin, ürün dağılımını önemli ölçüde etkilediği görülmüştür. 5Ni-3Ru@ $\mathrm{Al}_{2}\left(\mathrm{SiO}_{2}\right)_{3}$ ve $5 \mathrm{Ni}-3 \mathrm{CeO}_{2} @ \mathrm{Al}_{2}\left(\mathrm{SiO}_{2}\right)_{3}$ katalizörleri

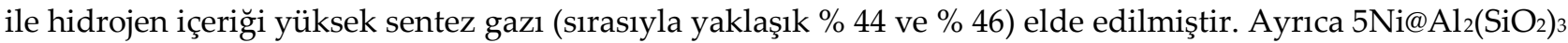
katalizörüne $\mathrm{MgO}$ ilavesi hidrojen seçiciliğini oldukça etkilemiştir. $5 \mathrm{Ni}-3 \mathrm{MgO} @ \mathrm{Al}_{2}\left(\mathrm{SiO}_{2}\right)_{3}$ katalizörü ile eşit molarda $\mathrm{H}_{2}$ ile $\mathrm{CO}$ içeren ve Fischer-Tropsch prosesi için önemli bir ham madde olan sentez gazı elde edilmiştir.

Anahtar Kelimeler: Nikel, Ticari alüminosilikat, Asetik asit, Buharl reformlanma reaksiyonu, Hidrojen

UKMK2020: 14. Ulusal Kimya Mühendisliği Kongresi'nde sunulan bildiriler arasından seçilmiştir. (10-12 Haziran 2021 Konya, TÜRKİYE) 


\section{INTRODUCTION}

Hydrogen's unique properties, namely high conversion efficiency (2.75 times more energy than natural gas), high energy content $(142 \mathrm{~kJ} / \mathrm{g})$, and the ability to be converted, stored, and transported under various forms (such as gaseous or liquid), make it a potential candidate to be the best fuel of the future (Phung et al., 2020). Additionally, the nonpolluting nature, the versatile applications, and the suitability for continuous use make hydrogen the appropriate alternative energy carrier to decarbonize the energy sector (Zhang et al., 2014). However, the most common raw materials of hydrogen production are fossil fuel-based resources such as heavy oil, coal, naphtha, and natural gas (Choi et al., 2019; Fu et al., 2019; Omoregbe et al., 2017). The main technologies used to generate hydrogen are methane steam reforming, autothermal reforming, dry reforming, gasification, and pyrolysis, cracking, thermo-chemical water splitting, fermentation, photo fermentation, biophotolysis, microbial electrolysis, and biomass dark fermentation (Cakiryilmaz et al., 2018; Basagiannis et al., 2007; Rodrigues et al., 2020). However, a significant amount of $\mathrm{CO}_{2}$ is released during the production of hydrogen following most of these technologies. One of the most promising and economic paths to generate hydrogen is the steam reforming of biomass-based bio-oil (Ozel et al., 2020). With the rapid consumption of fossil fuel reserves, the increase in energy demand, population growth, and emerging economies coupled with environmental issues such as global warming and pollution, hydrogen production from alternative sources such as bio-oil have attracted the attention of many researchers (Zdravkov et al., 2007). Conversion of biomassderived biogas into syngas $\left(\mathrm{H}_{2}+\mathrm{CO}\right)$, which is a usable chemical product, is an alternative to meet this need (Goicoechea et al., 2015). Synthesis gas obtained as a result of the reaction known as the steam reforming of acetic acid is important because it is both an energy store and a valuable chemical product that can be used as a raw material in the production of several liquid hydrocarbons. In addition, the $\mathrm{H}_{2} / \mathrm{CO}$ ratio of synthesis gas produced by dry reforming and partial oxidation of methane is 3 and 2, respectively, while the ratio of $\mathrm{H}_{2}$ to $\mathrm{CO}$ in the synthesis gas comes from the steam reforming of acetic acid is close to one, which is suitable for the subsequent production of oxygen-containing chemicals and long-chain hydrocarbons in downstream and dimethyl ether (Omoregbe et al., 2017).

Bio-oil is a suitable feedstock for steam reforming with higher energy content, facile storage, and transportation than biomass. Bio-oil is a complex combination of alcohols, sugars, acids, esters, aldehydes, and ketones (Sahin et al., 2019). Acetic acid, produced through flash pyrolysis, is the principal compound of bio-oil (Morris et al., 2008). As a result, acetic acid is used as a model compound of the steam reforming reaction for alternative hydrogen production. The main benefits of using acetic acid as a model compound in the steam reforming process are namely the simple operation and the high efficiency of hydrogen at low reaction temperature over suitable Ni-based catalysts. Moreover, unlike alcohols (methanol and ethanol), acetic acid is a nonflammable and a safe hydrogen carrier. Steam reforming is used to break down bio-oil into light fraction to get hydrogen-rich gas (Chen et al., 2020).

The fundamental reforming reaction $\left(\mathrm{CH}_{3} \mathrm{COOH}+2 \mathrm{H}_{2} \mathrm{O} \rightleftharpoons 2 \mathrm{CO}_{2}+4 \mathrm{H}_{2}\right)$ is the addition of thermal acetic acid decomposition $\left(\mathrm{CH}_{3} \mathrm{COOH} \rightleftharpoons 2 \mathrm{CO}+2 \mathrm{H}_{2}\right)$ and water gas shift reaction $\quad\left(\mathrm{CO}+\mathrm{H}_{2} \mathrm{O} \rightleftharpoons \mathrm{CO}_{2}+\mathrm{H}_{2}\right)$ (Karaman et al., 2017; Zhang et al., 2019; Chen et al., 2017). Nevertheless, according to the reaction parameters and the catalysts properties, some main side reactions, including decarboxylation reaction $\left(\mathrm{CH}_{3} \mathrm{COOH} \rightleftharpoons \mathrm{CH}_{4}\right.$ $\left.+\mathrm{CO}_{2}\right)$, methanation reaction $\left.\left(2 \mathrm{CH}_{3} \mathrm{COOH} \rightleftharpoons \mathrm{CH}_{3}\right)_{2} \mathrm{CO}+\mathrm{CO}_{2}+\mathrm{H}_{2} \mathrm{O}\right)$, methane cracking $\left(\mathrm{CH}_{4} \leftrightarrow \mathrm{C}+2 \mathrm{H}_{2}\right)$ and Boudouard reaction $\left(2 \mathrm{CO} \rightleftharpoons \mathrm{C}+\mathrm{CO}_{2}\right.$ ) may occur (Karaman et al., 2017; Goicoechea et al., 2015; An et al., 2011; Basile et al., 2008). The occurrence of these secondary reactions lessens the reforming reaction performance and lowers the desired product $\left(\mathrm{H}_{2}\right)$ selectivity (Nbgan et al., 2016).

Furthermore, the incidence of methane decomposition and Boudouard reactions lead to catalyst deactivation and metal sintering (Zhang et al., 2018). Thus, catalyst performance and catalyst lifetime are reduced. The essential gaseous products generated from the steam reforming of acetic acid are hydrogen $\left(\mathrm{H}_{2}\right)$, carbon monoxide (CO), methane $\left(\mathrm{CH}_{4}\right)$, and carbon dioxide $\left(\mathrm{CO}_{2}\right)$ (Wang et al., 2015). Steam reforming is an 
endothermic reaction, which is strongly selective at higher temperatures (Sahin et al., 2019). For this reason, Ni-based catalysts with high thermal, mechanical, and chemical resistance are required. Besides, Ni-based catalysts are highly active in cracking the C-C, C-H and C-O bonds and generating clean hydrogen (Karaman et al., 2017; Ozel et al., 2020; Chen et al., 2018; Thangadurai et al., 2020; Omoregbe et al., 2016). Nevertheless, the major problem which has been encountered during the reforming reaction is the fast deactivation of $\mathrm{Ni}$ containing catalysts, generally due to carbon formation and metal (Ni) sintering (Zang et al., 2019; Hu et al., 2017; Wang et al., 2017). To reduce coke deposition and to increase the catalyst stability, suitable promotors such as $\mathrm{MgO}, \mathrm{La}_{2} \mathrm{O}_{3}, \mathrm{CeO}_{2}$, and $\mathrm{CaO}$ must be introduced into the catalyst structure (Chong et al., 2019). Basic promotors addition does not only facilitate metallic Ni dispersion and strengthen metal-support interaction, but also enhance catalysts stability and improve carbon dioxide adsorption by increasing the reverseBoudouard reaction for coke elimination (Yang et al., 2016). Many active metals (Ni, Co, Ru, Pd, Pt) and catalyst supports (SBA-15, CMK-3, MCM-41, $\mathrm{MgO}, \mathrm{Al}_{2} \mathrm{O}_{3}$ ) were tested in the steam reforming of acetic acid, from carriers with acidic properties to supports with basic characteristics. Many types of metal oxides were used as carriers for Ni-containing catalysts in the steam reforming of acetic acid. Previously reported studies showed that the acid-base properties of the support have a significant effect on the catalytic performance of the catalysts (Nabgan et al., 2017). For this reason, basic promotors and acidic catalyst support were used in this study. To the best of our knowledge, Ni-based commercial aluminosilicate $\left(\mathrm{Al}_{2}\left(\mathrm{SiO}_{2}\right)_{3}\right)$ supported catalysts for the steam reforming of acetic acid were not reported before.

In the present study, commercial aluminosilicate $\left(\mathrm{Al}_{2}\left(\mathrm{SiO}_{2}\right)_{3}\right)$ is used as catalyst support. $\mathrm{Ni}, \mathrm{Ni}-\mathrm{MgO}, \mathrm{Ni}-$ $\mathrm{La}_{2} \mathrm{O}_{3}, \mathrm{Ni}-\mathrm{CeO}_{2}, \mathrm{Ni}-\mathrm{CaO}$ and Ni-Ru-containing catalysts were prepared following a wet-impregnation method. The synthesized catalysts were characterized and tested for hydrogen production through steam reforming of biomass-derived acetic acid. The results obtained revealed that the catalytic performance of the reforming reaction depends strongly on the catalyst support, promotors, and reaction parameters.

\section{MATERIAL AND METHOD}

In this study, commercial aluminosilicate $\left(\left(\mathrm{Al}_{2}\left(\mathrm{SiO}_{2}\right)_{3}\right.\right.$, Merck) was used as catalyst support. $\mathrm{Ni}$, Ni-MgO, $\mathrm{Ni}-\mathrm{La}_{2} \mathrm{O}_{3}, \mathrm{Ni}-\mathrm{CeO}_{2}, \mathrm{Ni}-\mathrm{CaO}$ and $\mathrm{Ni}-\mathrm{Ru}$-containing catalysts were developed by the addition of metals contents to the mesoporous $\left(\mathrm{Al}_{2}\left(\mathrm{SiO}_{2}\right)_{3}\right.$ catalyst support structure through the wet impregnation route.

For this reason, nickel (II) nitrate hexahydrate $\left(\mathrm{Ni}\left(\mathrm{NO}_{3}\right)_{2} .6 \mathrm{H}_{2} \mathrm{O}\right.$, Merck), magnesium nitrate hexahydrate $\left(\mathrm{Mg}\left(\mathrm{NO}_{3}\right)_{2} .6 \mathrm{H}_{2} \mathrm{O}\right.$, Merck), lanthanum (III) chloride heptahydrate $\left(\mathrm{LaCl}_{3} .7 \mathrm{H}_{2} \mathrm{O}\right.$, Sigma-Aldrich), cerium (III) nitrate hexahydrate $\left(\mathrm{Ce}\left(\mathrm{NO}_{3}\right)_{3} .6 \mathrm{H}_{2} \mathrm{O}\right.$, Merck), calcium nitrate tetrahydrate $\left(\mathrm{Ca}\left(\mathrm{NO}_{3}\right)_{2} .4 \mathrm{H}_{2} \mathrm{O}\right.$, Sigma-Aldrich) and ruthenium (III) chloride hydrate $\left(\mathrm{RuCl}_{3} \cdot \mathrm{xH}_{2} \mathrm{O}\right.$, Sigma-Aldrich) were used as the $\mathrm{Ni}, \mathrm{Mg}, \mathrm{La}, \mathrm{Ce}, \mathrm{Ca}$, and $\mathrm{Ru}$ sources, respectively. The mono-metallic catalyst was synthesized first by dissolving $\mathrm{Al}_{2}\left(\mathrm{SiO}_{2}\right)_{3}$ contents into distilled water. Next, the metal (Ni) source was dissolved separately in deionized water.

The independently prepared aqueous solutions were slowly mixed under continuous stirring at $40 \mathrm{C}$ to vaporize the solvent. Afterwards, the as-prepared mono-metallic catalyst $\left(5 \mathrm{Ni} @\left(\mathrm{Al}_{2}\left(\mathrm{SiO}_{2}\right)_{3}\right)\right.$ was calcinated at $800 \mathrm{C}$ for 6 hours under the flow of dry air. The calcination process was carried out slowly by increasing the temperature from room temperature to $800 \mathrm{C}$ at a heating rate of $1 \mathrm{C} / \mathrm{min}$ and maintained at $800 \mathrm{C}$ for 6 hours. Bi-metallic catalysts were developed through a wet impregnation method. To do so, catalyst support, nickel source $(\% 5 \mathrm{Ni})$ and the promotors source $(\mathrm{Mg}, \mathrm{La}, \mathrm{Ce}, \mathrm{Ca}$, and $\mathrm{Ru})$ have been individually dispersed into distilled water. Then the active metal source's solutions were introduced gradually to the material support solution. The solvent (water) was vaporized at $40 \mathrm{C}$ under vigorous stirring.

Finally, the as-obtained solid contents have been calcinated at $800 \mathrm{C}$ using the same procedure described above. All the prepared catalysts were reduced at $750 \mathrm{C}$ under the flow of hydrogen for 1 hour. This process was performed by slowly increasing the temperature from $25^{\circ} \mathrm{C}$ to $750 \mathrm{C}$ at a heating rate of $10 \mathrm{C} / \mathrm{min}$ and kept at $750 \mathrm{C}$ for 1 hour.

UKMK2020: 14. Ulusal Kimya Mühendisliği Kongresi'nde sunulan bildiriler arasından seçilmiştir. (10-12 Haziran 2021 Konya, TÜRKIYYE) 
To determine their physicochemical properties, the synthesized catalysts were characterized by X-ray powder diffraction (XRD), scanning electron microscopy (SEM), nitrogen adsorption-desorption and thermogravimetric and differential thermal analysis (TGA-DTA) were recorded. Wide XRD diffraction patterns were carried out via Rigaku D/MAX 2200 diffractometer outfitted with a $\mathrm{Cu} K_{\alpha}$ X-ray source at the rate of $2 \% \mathrm{~min}$. SEM images of the synthesized catalysts were specified using the QUANTA 400F Field Emission high-resolution scanning electron microscope device. The BET surface areas, pore sizes, and pore volumes of the prepared catalysts have been determined through the Brunauer-Emmett-Teller (BET) approach utilizing a Quanta Chrome Autosorp 6 physical adsorption apparatus at $77 \mathrm{~K}$ (Karaman et al., 2017). Before the process, each sample was degassed under high vacuum at a temperature of $120 \mathrm{C}$ for 2 hours to empty the catalyst pores. Subsequently, $\mathrm{N}_{2}$ adsorption-desorption isotherms were recorded. The TGA-DTA analysis of the spent catalysts was carried out via Perkin Elmer Pyris 1 thermogravimetric analysis apparatus.

The analysis of the spent catalysts was performed from ambient temperature to $900 \mathrm{C}$ at a heating rate of $10^{\circ} \mathrm{C} /$ min under the flow of dry air.

The reforming reaction of acetic acid was carried out in a conventional reaction system using a quartz tubular flow reactor with an inner diameter of $6 \mathrm{~mm}$. Before each experiment, $0.1 \mathrm{~g}$ of pelletized catalysts with dimensions ranging from 1 to $2 \mathrm{~mm}$ have been placed in the center of the reactor and supported from both sides by means of quartz wool. All the experiments were conducted at $750 \mathrm{C}$ and at ambient pressure.

The feedstock stream is composed of acetic acid and water at a molar ratio of 2.5. The liquid mixture was sent to an evaporator using a syringe pump and volatilized at $150 \mathrm{C}$. The volatilized mixture at a rate of 52.5 $\mathrm{mL} / \mathrm{min}$ was combined with argon flowing at $30 \mathrm{~mL} / \mathrm{min}$. The total gas stream flowing at $82.5 \mathrm{~mL} / \mathrm{min}$ was fed to the reactor. Unconsumed liquid products (Acetic acid and water) have been collected in the condenser. The effluent gas products $\left(\mathrm{H}_{2}, \mathrm{CO}, \mathrm{CH}_{4}, \mathrm{CO}_{2}\right)$ were analyzed via an online gas chromatograph apparatus fitted out with a Porapak S column and thermal conductivity detector. Acetic acid conversion and gaseous products selectivity values were defined using unreacted liquid products and effluent gas products composition determined in the gas chromatograph device. Consider $\left(\mathrm{n}_{\mathrm{AA}}\right)_{\mathrm{in}},\left(\mathrm{n}_{\mathrm{AA}}\right)_{\text {out }}$, and $\mathrm{n}_{\mathrm{i}}$ to be the moles of acetic acid in the feedstock, the moles of unconsumed acetic acid and the moles of gaseous product i produced, respectively. AA conversion, $\mathrm{H}_{2}, \mathrm{CO}, \mathrm{CH}_{4}$ and $\mathrm{CO}_{2}$ selectivities were calculated using (Eqs.(1-3)).

Acetic Acid (AA) conversion: $\mathrm{X}_{\mathrm{AA}}=\frac{\left(\mathrm{n}_{\mathrm{AA}}\right)_{\text {in }}-\left(\mathrm{n}_{\mathrm{AA}}\right)_{\text {out }}}{\left(\mathrm{n}_{\mathrm{AA}}\right)_{\text {in }}} \times 100 \%$
Hydrogen selectivity: $\mathrm{S}_{\mathrm{H}_{2}}=\frac{\mathrm{n}_{\mathrm{H}_{2}}}{4 \times\left(\left(\mathrm{n}_{\mathrm{AA}}\right)_{\text {in }}-\left(\mathrm{n}_{\mathrm{AA}}\right)_{\text {out }}\right)} \times 100 \%$
$\mathrm{CO}, \mathrm{CH}_{4}$ and $\mathrm{CO}_{2}$ selectivity: $\mathrm{S}_{\mathrm{CO}, \mathrm{CH}_{4}, \mathrm{CO}_{2}}=\frac{\mathrm{n}_{\mathrm{CO}, \mathrm{CH}_{4}, \mathrm{CO}_{2}}}{2 \times\left(\left(\mathrm{n}_{\mathrm{AA}}\right)_{\text {in }}-\left(\mathrm{n}_{\mathrm{AA}}\right)_{\text {out }}\right)} \times 100 \%$

\section{RESULT AND DISCUSSION}

\subsection{Characterization Results}

Nitrogen adsorption-desorption isotherm and pore size distribution graph of the pure $\mathrm{Al}_{2}\left(\mathrm{SiO}_{2}\right)_{3}$ catalyst are presented in Figure 1A and Figure 1B, respectively. According to IUPAC classification, the pure $\mathrm{Al}_{2}\left(\mathrm{SiO}_{2}\right)_{3}$ catalyst presents the typical type IV isotherm behaviour along with $\mathrm{H} 3$ hysteresis loop characteristic for platelike materials. In addition, the step capillary condensation observed at a relative pressure ranging from 0.8 to 0.96 indicates the formation of uniform porous materials. The commercial $\mathrm{Al}_{2}\left(\mathrm{SiO}_{2}\right)_{3}$ is a mesoporous catalyst with a surface area of $58.55 \mathrm{~m}^{2} / \mathrm{g}$ and an average pore diameter of $3.35 \mathrm{~nm}$, respectively.

The pore size distribution curve determined by BJH method indicates the presence of narrow peaks within the mesoporous region. 
The X-ray diffraction pattern of the pure $\mathrm{Al}_{2}\left(\mathrm{SiO}_{2}\right)_{3}$ is shown in Figure 1C. The clear peak observed in the XRD spectrum at $2 \theta=21.94^{\circ}$ is associated with the amorphous aluminosilicate phase. The resulting characteristic peak is consistent with previous literature studies (Karaman et al., 2017).
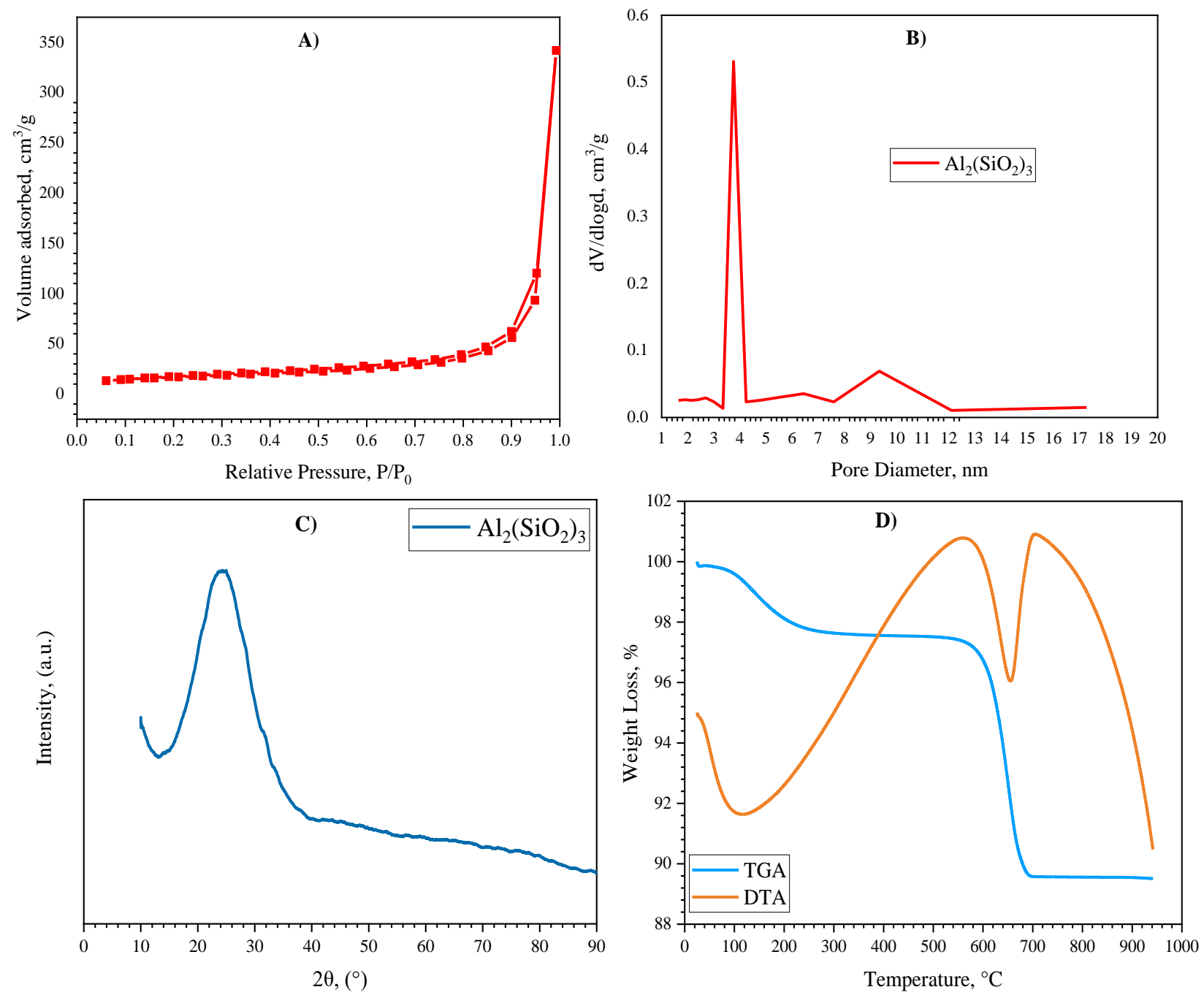

Figure 1. A) $\mathrm{N}_{2}$ adsorption-desorption isotherm, B) Pore size distribution, C) X-ray diffraction spectra and D) TGA-DTA analysis of pure $\mathrm{Al}_{2}\left(\mathrm{SiO}_{2}\right)_{3}$ catalyst support

TGA-DTA analysis used to determine the calcination temperature and weight loss of the uncalcinated $\mathrm{Al}_{2}\left(\mathrm{SiO}_{2}\right)_{3}$ catalyst with increasing temperature is illustrated in Figure 1D. According to reported studies, the initial weight loss (up to $400 \mathrm{C}$ ) is due to the removal of volatile compounds, water or gases adsorbed on the surface of the catalyst.

Besides, the oxidation peak observed at $700 \mathrm{C}$ is linked to the combustion or decomposition of organic compounds in the catalyst's surface. Beyond $700 \mathrm{C}$, no phase transformation was seen. Hence, temperatures of $700 \mathrm{C}$ and above are suitable for catalyst calcination.

SEM images of pure $\mathrm{Al}_{2}\left(\mathrm{SiO}_{2}\right)_{3}$ material are shown in Figure 2. We observe that the pure material exhibited tiny spherical morphology. The tiny particles are highly connected to each other forming nanosheet-like agglomerates with particle sizes ranging from 3 to $5 \mu \mathrm{m}$. 

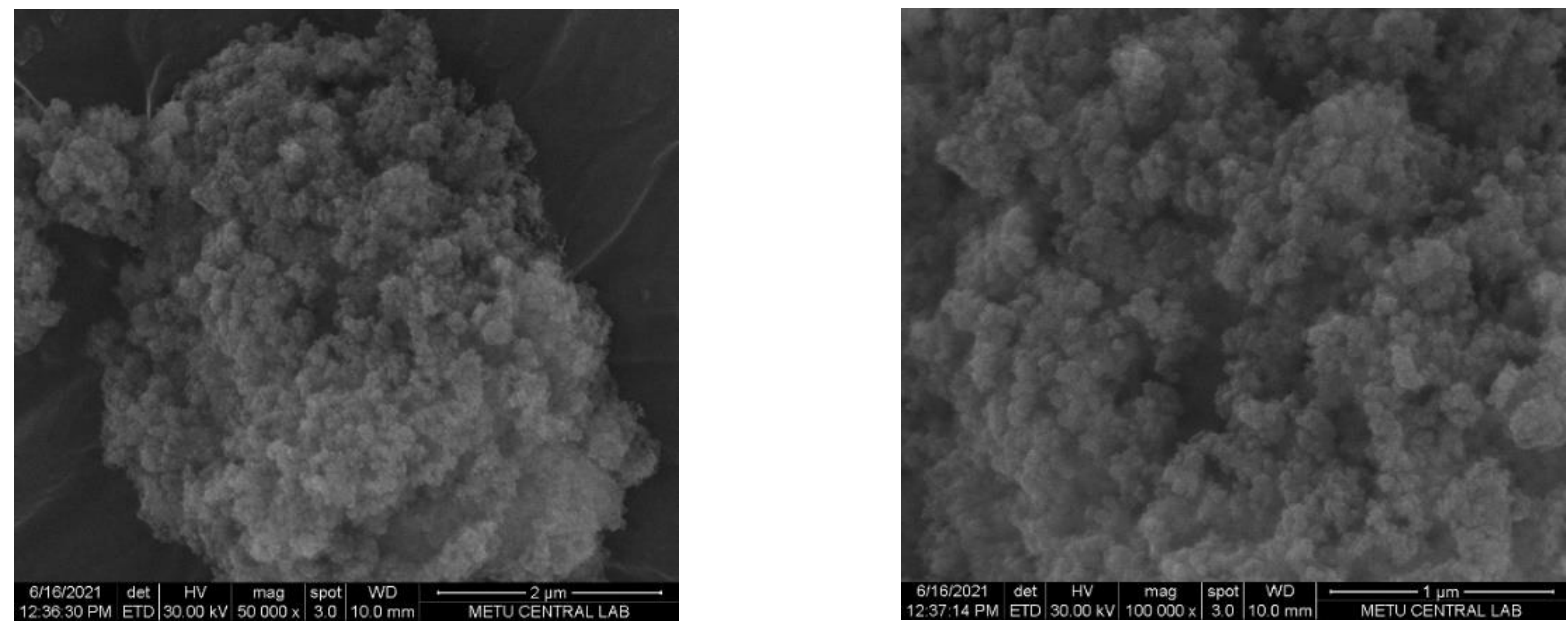

Figure 2. SEM images of pure $\mathrm{Al}_{2}\left(\mathrm{SiO}_{2}\right)_{3}$ catalyst support

Nitrogen adsorption-desorption isotherms of metal-containing catalysts calcinated at $800 \mathrm{C}$ are given in Figure 3. The isotherm branches are type IV with $\mathrm{H} 3$ hysteresis loops characteristic for aggregates of platelike species composing slit-shaped pores. The mesoporous $5 \mathrm{Ni}-3 \mathrm{La}_{2} \mathrm{O}_{3} @ \mathrm{Al}_{2}\left(\mathrm{SiO}_{2}\right)_{3}$ catalyst has a higher adsorption capacity than the other catalysts. The amount of the adsorbed volume at a relative pressure of 0.95 increases from $51.7 \mathrm{~cm}^{3} / \mathrm{g}$ to $274.5 \mathrm{~cm}^{3} / \mathrm{g}$. At low relative pressure, below $\mathrm{P} / \mathrm{P}_{0}=0.02$, no sharp increase in nitrogen volume and no gas adsorption amount has been seen, which confirms that is no micropores in the analyzed samples. At relative pressure ranging from $\mathrm{P} / \mathrm{P}_{0}=0.05$ to $\mathrm{P} / \mathrm{P}_{0}=0.95$, the content of the adsorbed nitrogen increases from $6.8 \mathrm{~cm}^{3} / \mathrm{g}$ to $51.7 \mathrm{~cm}^{3} / \mathrm{g}$. This behavior indicates the porous nature with the presence of both mesopores and macropores in the samples. Thus, this significant increase is due to the complete filling of mesopores and partial filling of macropores effect. The surface areas, pore volumes and pore diameters calculated from desorption isotherm branches are listed in Table 1. The specific surface area of the pure catalyst was $58.55 \mathrm{~m}^{2} / \mathrm{g}$. Ni incorporation decreases the surface areas and the average pore volumes of catalysts. This decrease in BET surface areas and average pore volume is directly linked to the partial blockage of the $\mathrm{Al}_{2}\left(\mathrm{SiO}_{2}\right)_{3}$ pores or the partial collapse of the crystal structure.

Besides, the pore diameters of the corresponding catalysts are shown in Table 1. As seen from Table 1, comparatively narrow-diameters were obtained, which further suggest the presence of uniform mesostructures in the samples. The pore diameters of the synthesized catalysts determined by BJH method are ranging from 3 and $10 \mathrm{~nm}$. 
Table 1. Physical properties of $\mathrm{Ni}$ containing $\mathrm{Al}_{2}\left(\mathrm{SiO}_{2}\right)_{3}$ supported catalysts prepared by wet impregnation method

\begin{tabular}{lccc}
\hline Catalysts & Surface area $\left(\mathrm{m}^{2} / \mathrm{g}\right)$ & Pore size $(\mathrm{nm})$ & Pore volume $\left(\mathrm{cm}^{3} / \mathrm{g}\right)$ \\
\hline $\mathrm{Al}_{2}\left(\mathrm{SiO}_{2}\right)_{3}$ & 58.55 & 3.35 & 0.185 \\
$5 \mathrm{Ni} @ \mathrm{Al}_{2}\left(\mathrm{SiO}_{2}\right)_{3}$ & 25.40 & 3.34 & 0.082 \\
$5 \mathrm{Ni}-3 \mathrm{MgO} @ \mathrm{Al}_{2}\left(\mathrm{SiO}_{2}\right)_{3}$ & 20.65 & 5.47 & 0.072 \\
$5 \mathrm{Ni}-3 \mathrm{La}_{2} \mathrm{O}_{3} @ \mathrm{Al}_{2}\left(\mathrm{SiO}_{2}\right)_{3}$ & 36.86 & 7.69 & 0.132 \\
$5 \mathrm{Ni}-3 \mathrm{CeO}_{2} @ \mathrm{Al}_{2}\left(\mathrm{SiO}_{2}\right)_{3}$ & 23.57 & 5.45 & 0.069 \\
$5 \mathrm{Ni}-3 \mathrm{CaO} @ \mathrm{Al}_{2}\left(\mathrm{SiO}_{2}\right)_{3}$ & 8.407 & 9.15 & 0.053 \\
$5 \mathrm{Ni}-3 \mathrm{Ru} @ \mathrm{Al}_{2}\left(\mathrm{SiO}_{2}\right)_{3}$ & 32.12 & 6.37 & 0.090 \\
\hline
\end{tabular}

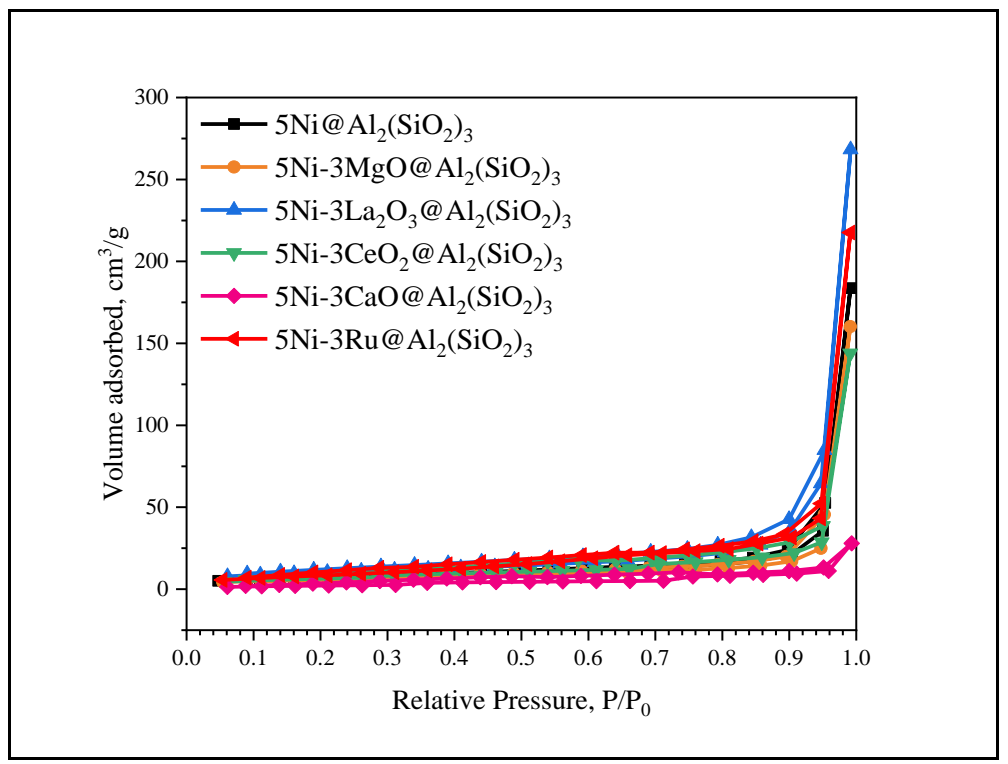

Figure 3. $\mathrm{N}_{2}$ adsorption-desorption isotherm branches of metal-containing $\mathrm{Al}_{2}\left(\mathrm{SiO}_{2}\right)_{3}$ supported catalysts

Figure 4 depicts the XRD diffraction patterns of calcinated metal containing $\mathrm{Al}_{2}\left(\mathrm{SiO}_{2}\right)_{3}$ supported catalysts. The diffractogram reveals some broad amorphous peaks between $20-30^{\circ}$ and particularly at $44.6^{\circ}, 52.1^{\circ}$ and $76.7^{\circ}$ due to the reflection of X-ray from one crystalline plane to another. The clear peak recorded at $21.94^{\circ}$ shows that the mesoporous $\mathrm{Al}_{2}\left(\mathrm{SiO}_{2}\right)_{3}$ catalyst support retains its crystal structure after the integration of $\mathrm{Ni}$ and basic promotors. This result confirms that $\mathrm{Ni}$ species and basic promotors were successfully loaded into the $\mathrm{Al}_{2}\left(\mathrm{SiO}_{2}\right)_{3}$ catalyst support structure. The $\mathrm{X}$-ray diffraction peaks observed at $2 \theta=44.6^{\circ}, 51.9^{\circ}$ and $76.7^{\circ}$ are assigned to the metallic Ni phase (Murata et al., 2004). The addition of promotors remarkably affected the crystal structure of the catalysts. As a result, intense peaks were identified at $2 \theta=44.6^{\circ}$ after the introduction of $\mathrm{MgO}, \mathrm{La}_{2} \mathrm{O}_{3}, \mathrm{CeO}_{2}$ and $\mathrm{Ru}$ into the catalyst structure. Additionally, characteristic peaks corresponding to $\mathrm{MgO}, \mathrm{La}_{2} \mathrm{O}_{3}, \mathrm{CeO}_{2}, \mathrm{CaO}$ and $\mathrm{Ru}$ were detected and labeled in the XRD graph. This result confirms the homogeneous dispersion of metallic species on the surface of the support material. 


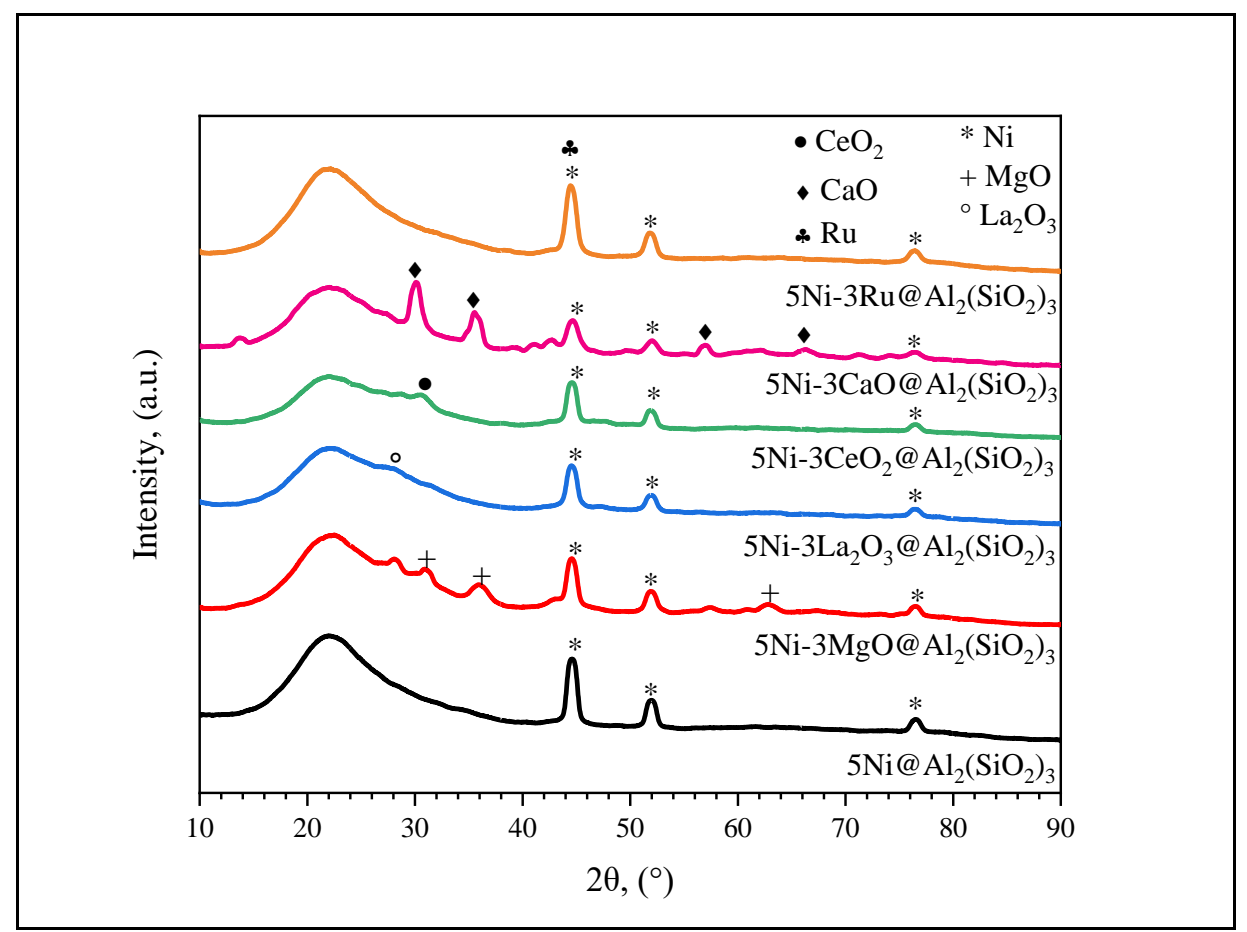

Figure 4. XRD diffraction patterns of $\mathrm{Ni}$ and/or $\mathrm{Mg}$ containing $\mathrm{Al}_{2}\left(\mathrm{SiO}_{2}\right)_{3}$ supported catalysts

SEM images of metal-containing $\mathrm{Al}_{2}\left(\mathrm{SiO}_{2}\right)_{3}$ supported catalysts synthesized by the wet impregnation route are given in Figure 5. As can be seen from Figure 5, various structures with different morphologies have been observed, which stem from the aggregation of species. These particles connected closely to each other form the slit-like wall structures. After the introduction of $\mathrm{Mg}$ into the structure of the catalyst support, slit-like structure changed slightly, and clear plate-like particles were observed. While tiny particles were seen with $\mathrm{CeO}_{2}$ incorporation, slightly large particles were observed after $\mathrm{La}$ and $\mathrm{Ru}$ addition. 

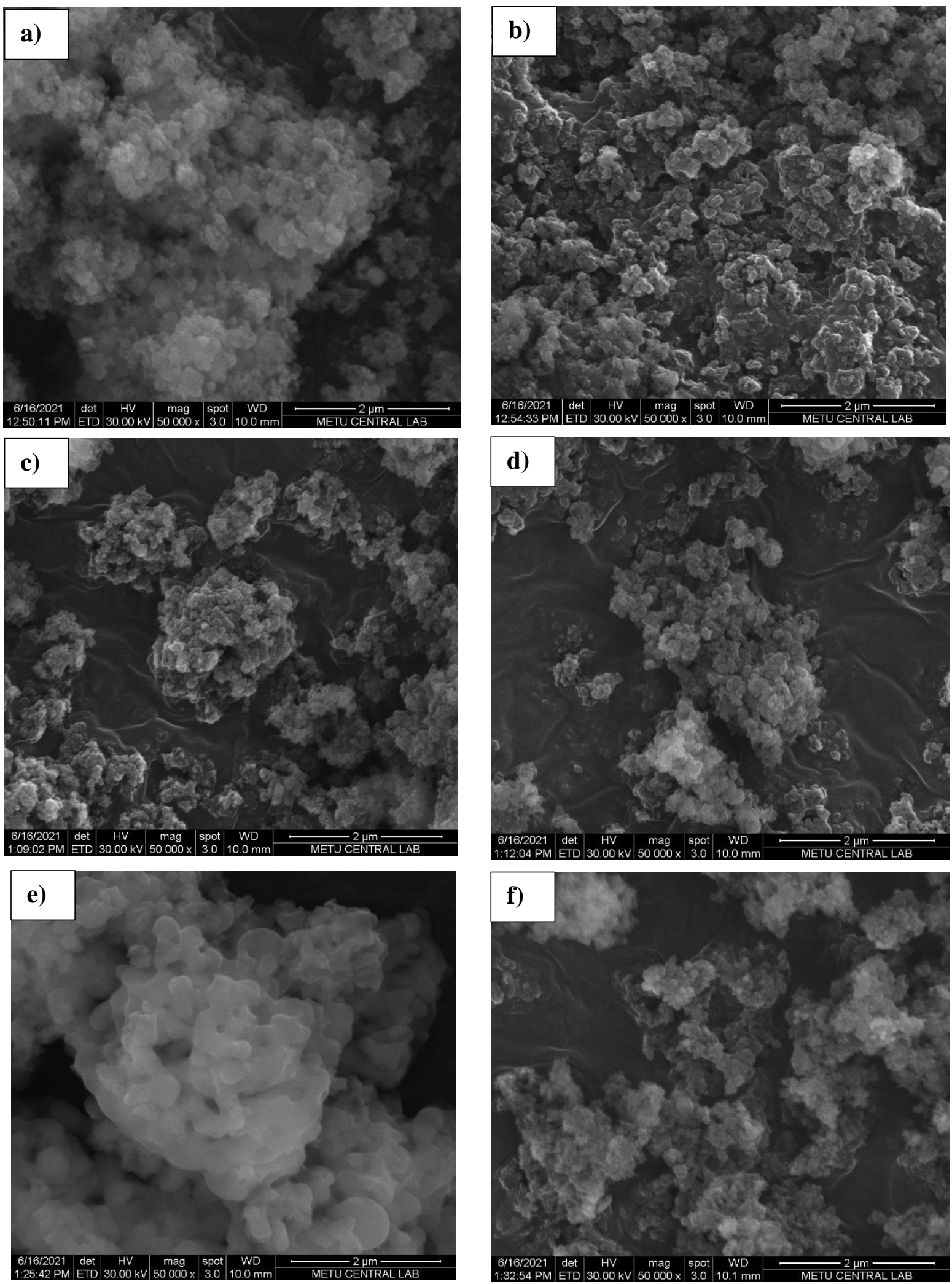

Figure 5. SEM images of a) $\left.\left.\mathrm{Ni} @ \mathrm{Al}_{2}\left(\mathrm{SiO}_{2}\right)_{3}, \mathbf{b}\right) \mathrm{Ni}-3 \mathrm{MgO} @ \mathrm{Al}_{2}\left(\mathrm{SiO}_{2}\right)_{3}, \mathbf{c}\right) \mathrm{Ni}-3 \mathrm{La}_{2} \mathrm{O}_{3} @ \mathrm{Al}_{2}\left(\mathrm{SiO}_{2}\right)_{3}$, d) $\mathrm{Ni}-$ $3 \mathrm{CeO}_{2} @ \mathrm{Al}_{2}\left(\mathrm{SiO}_{2}\right)_{3}$, e) Ni-3CaO@ $\mathrm{Al}_{2}\left(\mathrm{SiO}_{2}\right)_{3}$ and f) $\mathrm{Ni}-3 \mathrm{Ru} @ \mathrm{Al}_{2}\left(\mathrm{SiO}_{2}\right)_{3}$ catalysts 


\subsection{Activity Test Results}

Steam reforming of acetic acid was carried out over various catalysts at a reaction temperature of $750 \mathrm{C}$, a feedstock molar composition of $\mathrm{H}_{2} \mathrm{O} / \mathrm{AA}: 2.5 \mathrm{~mol} / \mathrm{mol}$ and a liquid flow rate of $2.82 \mathrm{~mL} / \mathrm{h}$ for $3 \mathrm{~h}$. The efficiencies of the prepared catalysts were measured with respect to conversion of acetic acid and selectivity of gaseous products $\left(\mathrm{H}_{2}, \mathrm{CO}, \mathrm{CH}_{4}, \mathrm{CO}_{2}\right)$. Product distribution of effluent gases, hydrogen selectivity values and acetic acid conversion of all the catalysts are listed in Table 2. To begin, an initial experiment was conducted using the pure, commercial catalyst support, $\mathrm{Al}_{2}\left(\mathrm{SiO}_{2}\right)_{3}$. The poorest activity performance was obtained over this catalyst by giving the lowest acetic acid conversion (71\%) and the lowest hydrogen selectivity (3\%). Quite high proportion of $\mathrm{CO}_{2}, \mathrm{CH}_{4}$, and $\mathrm{CO}$ were observed in the product composition. This is due to the occurence of the decarboxylation reaction $\left(\mathrm{CH}_{3} \mathrm{COOH} \rightleftharpoons \mathrm{CH}_{4}+\mathrm{CO}_{2}\right)$ of acetic acid and water gas shift reaction $\left(\mathrm{CO}+\mathrm{H}_{2} \mathrm{O} \rightleftharpoons \mathrm{CO}_{2}+\mathrm{H}_{2}\right)$.

To enhance the catalytic activity, to increase the selectivity of hydrogen and the conversion of acetic acid, $\mathrm{Ni}$-containing catalyst was prepared using a wet-impregnation method. Previous studies had shown that $\mathrm{Ni}$ containing catalysts are very selective for the steam reforming reaction (Guggilla et al., 2010). As expected, Ni addition in the material support had substantially improved the efficiency of steam reforming reaction. As can been seen from Table 2, Ni loading drastically ameliorated the selectivity of hydrogen to rise from $3 \%$ to $43.25 \%$, indicating the slight gaining control of the reforming reaction over the side reactions. A noticeable number of undesired products such as $\mathrm{CO}$ and $\mathrm{CO}_{2}$ were produced, resulting in a conversion of $83 \%$ and hydrogen selectivity of $43.25 \%$. The secondary reactions, such as water-gas shift reaction $\left(\mathrm{CO}+\mathrm{H}_{2} \mathrm{O} \rightleftharpoons \mathrm{CO}_{2}+\right.$ $\mathrm{H}_{2}$ ) predominantly took place in parallel with the steam reforming of acetic acid.

Table 2. Catalytic activity test results of the synthesized catalysts

\begin{tabular}{ccccccc}
\hline Catalysts & Conversion of & Selectivity of & \multicolumn{4}{c}{ Product distribution, \% } \\
& $\mathrm{AA}, \%$ & $\mathrm{H}_{2}, \%$ & $\underline{\mathrm{H}_{2}}$ & $\underline{\mathrm{CO}}$ & $\underline{\mathrm{CH}_{4}}$ & $\underline{\mathrm{CO}_{2}}$ \\
\hline $\mathrm{Al}_{2}\left(\mathrm{SiO}_{2}\right)_{3}$ & 71 & 3.000 & 5.70 & 23.80 & 25.1 & 45.40 \\
$5 \mathrm{Ni} @ \mathrm{Al}_{2}\left(\mathrm{SiO}_{2}\right)_{3}$ & 83 & 43.25 & 46.32 & 30.66 & 5.86 & 17.16 \\
$5 \mathrm{Ni}-3 \mathrm{MgO} @ \mathrm{Al}_{2}\left(\mathrm{SiO}_{2}\right)_{3}$ & 81 & 27.75 & 35.58 & 35.49 & 9.95 & 18.98 \\
$5 \mathrm{Ni}-3 \mathrm{La}_{2} \mathrm{O}_{3} @ \mathrm{Al}_{2}\left(\mathrm{SiO}_{2}\right)_{3}$ & 88 & 5.250 & 9.420 & 72.95 & 2.79 & 14.84 \\
$5 \mathrm{Ni}-3 \mathrm{CeO}_{2} @ \mathrm{Al}_{2}\left(\mathrm{SiO}_{2}\right)_{3}$ & 79 & 43.50 & 46.46 & 29.37 & 6.60 & 17.57 \\
$5 \mathrm{Ni}-3 \mathrm{CaO} @ \mathrm{Al}_{2}\left(\mathrm{SiO}_{2}\right)_{3}$ & 75 & 19.25 & 25.86 & 58.04 & 5.27 & 10.82 \\
$5 \mathrm{Ni}-3 \mathrm{Ru} @ \mathrm{Al}_{2}\left(\mathrm{SiO}_{2}\right)_{3}$ & 89 & 40.00 & 44.28 & 32.42 & 5.38 & 17.93 \\
\hline
\end{tabular}

Figure 6 presents the selectivities of gaseous products as a function of time. All the experiments were conducted using an aqueous solution of acetic acid with a $\mathrm{S} / \mathrm{C}$ ratio $=2.5$ and a space time $=0.072 \mathrm{~g} \mathrm{~s} / \mathrm{mL}$ at ambient pressure and $750 \mathrm{C}$ using argon as carrier gas. Noticeable variation in hydrogen selectivity was observed with increasing reaction time in almost all the catalysts. Various conversions of acetic acid ranging from 71 to $89 \%$ were achieved along 3 hours of time-on-stream. Slightly high hydrogen selectivity was obtained over the $5 \mathrm{Ni} @ \mathrm{Al}_{2}\left(\mathrm{SiO}_{2}\right)_{3}$ catalyst. Nevertheless, different effluent gas distributions were achieved, implying different activity performances in the reforming reaction, assigned to the role of promotor in side reactions. In this regard, hydrogen, carbon monoxide, methane and carbon dioxide selectivity distributions are shown in Figure 6.

To further improve the dispersion of the active metal $(\mathrm{Ni})$ and to ameliorate the prepared catalysts catalytic activity and thermal stability by increasing their mechanical and chemical properties, some metals such as $\mathrm{Mg}$, $\mathrm{La}, \mathrm{Ce}, \mathrm{Ca}$, and $\mathrm{Ru}$ have been added to the $5 \mathrm{Ni} @ \mathrm{Al}_{2}\left(\mathrm{SiO}_{2}\right)_{3}$ catalyst's structure. Among the synthesized catalysts, $5 \mathrm{Ni}-3 \mathrm{CeO}_{2} @ \mathrm{Al}_{2}\left(\mathrm{SiO}_{2}\right)_{3}$ showed the highest hydrogen selectivity of $43.50 \%$. 
At the beginning of the experiment, the steam reforming reaction was quite high with a hydrogen selectivity of $50.5 \%$. However, with increasing reaction time, hydrogen selectivity remarkably decreased to $41.75 \%$. This decrescent trend of hydrogen selectivity is explained by the fact that, the mesoporous $5 \mathrm{Ni}$ $3 \mathrm{CeO}_{2} @ \mathrm{Al}_{2}\left(\mathrm{SiO}_{2}\right)_{3}$ catalyst is not very selective for the reforming reaction towards hydrogen production. Besides, $79 \%$ of acetic acid conversion was achieved over this catalyst. This result suggests that the catalyst was not able to break down the C-C bond of the acetic acid and a large amount of by-products have been produced.

Moreover, $5 \mathrm{Ni}-3 \mathrm{La}_{2} \mathrm{O}_{3} @ \mathrm{Al}_{2}\left(\mathrm{SiO}_{2}\right)_{3}$ catalyst revealed the lowest selectivity towards hydrogen generation. It is apparent that this result is due to the poor dispersion of $\mathrm{Ni}$ and La species into the surface of the support. It gives the impression that catalytic activity is heavily attached to the structure of promotors in which the active metal is dispersed. The quite high conversion (88\%) and very low hydrogen yield of $5.25 \%$ have been obtained over this catalyst. In addition, the highest amount of $\mathrm{CO}(72.95 \%)$ and the lowest amount of $\mathrm{CH}_{4}$ $(2.79 \%)$ in the product distribution are produced with the $5 \mathrm{Ni}-3 \mathrm{La}_{2} \mathrm{O}_{3} @ \mathrm{Al}_{2}\left(\mathrm{SiO}_{2}\right)_{3}$ catalyst. This catalyst is effective in accompanying the thermal cracking of acetic acid $\left(\mathrm{CH}_{3} \mathrm{COOH} \rightleftharpoons 2 \mathrm{CO}+2 \mathrm{H}_{2}\right)$ over the reforming reaction.

Hydrogen yield is directly linked to the formation of undesired products such as methane, carbon monoxide and carbon dioxide. Hydrogen selectivity is reduced with increasing proportion of by-products in the product distribution. As expected, the incorporation of Ni contents into support with a large surface area and adjustable pore sizes increases the metal dispersion in the support material, thus improves the reforming reaction towards hydrogen production. While $19.25 \%$ of hydrogen selectivity was acquired with $5 \mathrm{Ni}$ $3 \mathrm{CaO} @ \mathrm{Al}_{2}\left(\mathrm{SiO}_{2}\right)_{3}$, a slightly high yield of $27.75 \%$ was achieved over $5 \mathrm{Ni}-3 \mathrm{MgO} @ \mathrm{Al}_{2}\left(\mathrm{SiO}_{2}\right)_{3}$ catalyst. As can be seen, carbon monoxide is the principal side product in the product distribution over both $5 \mathrm{Ni}$ $3 \mathrm{CaO} @ \mathrm{Al}_{2}\left(\mathrm{SiO}_{2}\right)_{3}$ and $5 \mathrm{Ni}-3 \mathrm{MgO} @ \mathrm{Al}_{2}\left(\mathrm{SiO}_{2}\right)_{3}$ catalysts with percentages of $58.04 \%$ and $35.49 \%$, respectively.

With these catalysts, carbon monoxide is the significant by-product, whereas a noticeable amount of carbon dioxide and trace amount of methane have been observed. In the case of $\quad 5 \mathrm{Ni}-3 \mathrm{Ru} @ \mathrm{Al}_{2}\left(\mathrm{SiO}_{2}\right)_{3}$ catalyst, quite important amounts of carbon monoxide (32.42\%) and carbon dioxide (17.93) are formed; however, the main product is hydrogen with a selectivity of $40 \%$ and an acetic acid conversion of $89 \%$.

In addition, through Fischer-Tropsch synthesis, valuable chemicals such as $\mathrm{H}_{2}+\mathrm{CO}$ with equimolar proportion were produced over the $5 \mathrm{Ni}-3 \mathrm{MgO} @ \mathrm{Al}_{2}\left(\mathrm{SiO}_{2}\right)_{3}$ catalyst. Syngas with a $\mathrm{H}_{2} / \mathrm{CO}$ equimolar ratio can be used to generate hydrocarbons through Fisher-Tropsch synthesis and/or direct synthesis of dimethyl ether, which is considered as one of the best alternates of diesel fuel due to its high cetane number. Besides, synthesis gas is quite important feedstock for Fischer-Tropsch process. In fact, the $\mathrm{H}_{2} / \mathrm{CO}$ molar ratio obtained at the optimum reaction condition is always less than the stoichiometric ratio of 4 , which further confirms the existence of side reactions such as reverse Boudouard reaction $\left(\mathrm{C}+\mathrm{CO}_{2} \rightleftharpoons 2 \mathrm{CO}\right)$ and reverse water-gas-shift reaction $\left(\mathrm{CO}_{2}+\mathrm{H}_{2} \rightleftharpoons \mathrm{CO}+\mathrm{H}_{2} \mathrm{O}\right)$ during the steam reforming of acetic acid. 

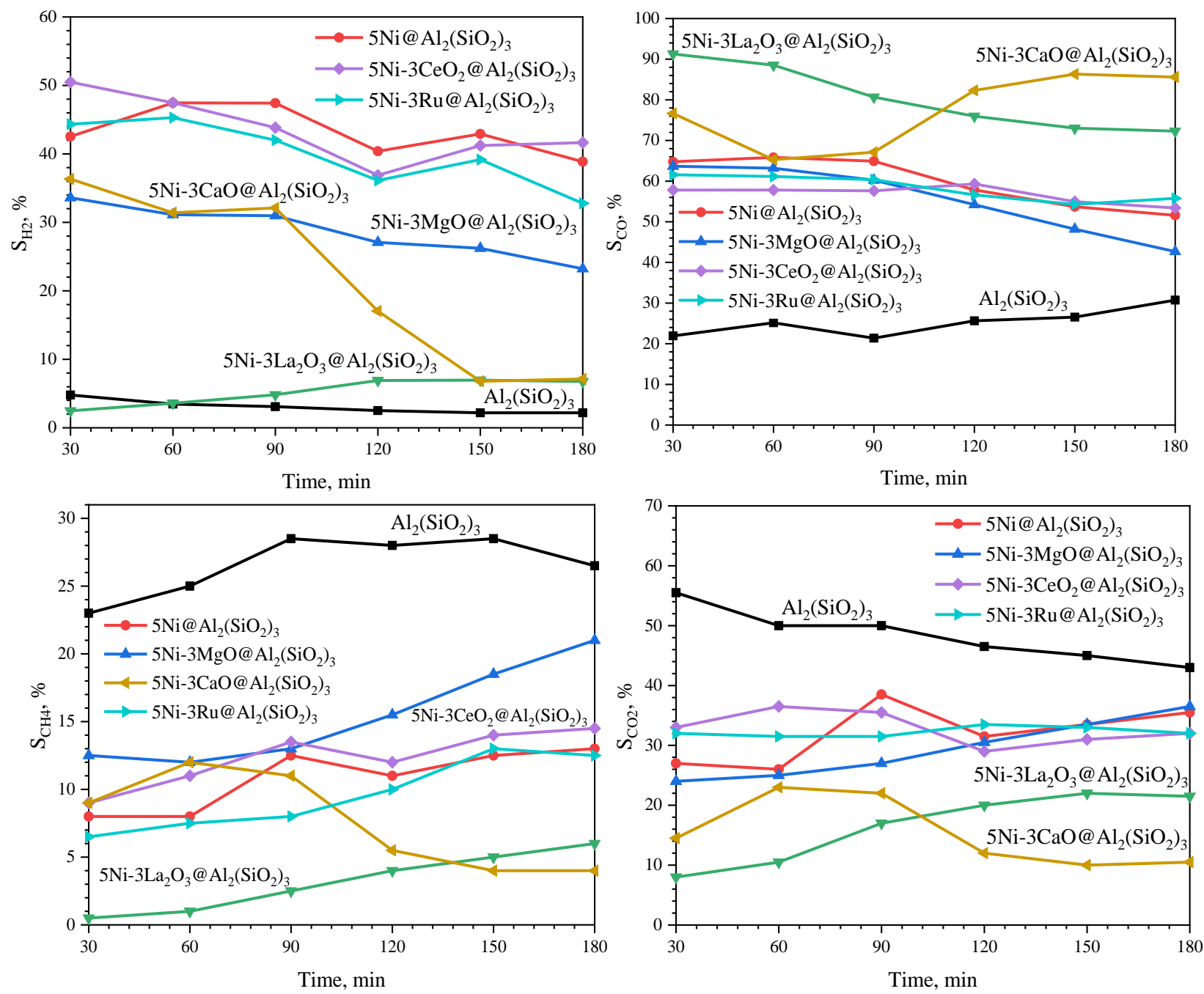

Figure 6. Gaseous products selectivity values of the synthesized catalysts

Expectedly, changing the nature of the basic promotor resulted in a fluctuation in hydrogen selectivity as well as $\mathrm{H}_{2} / \mathrm{CO}$ ratio. This result implies that although reverse Boudouard and reverse water-gas-shift reactions are thermodynamically feasible at elevated reaction temperatures, the steam reforming of acetic acid may exceed other secondary reactions, thereby increasing the $\mathrm{H}_{2} / \mathrm{CO}$ molar ratio. The ranking of Ni-containing catalysts based on their activity test performance appears to be as following: $5 \mathrm{Ni}$ $3 \mathrm{CeO}_{2} @ \mathrm{Al}_{2}\left(\mathrm{SiO}_{2}\right)_{3}>5 \mathrm{Ni} @ \mathrm{Al}_{2}\left(\mathrm{SiO}_{2}\right)_{3}>5 \mathrm{Ni}-3 \mathrm{Ru} @ \mathrm{Al}_{2}\left(\mathrm{SiO}_{2}\right)_{3}>5 \mathrm{Ni}-3 \mathrm{MgO} @ \mathrm{Al}_{2}\left(\mathrm{SiO}_{2}\right)_{3}>5 \mathrm{Ni}-3 \mathrm{CaO} @ \mathrm{Al}_{2}\left(\mathrm{SiO}_{2}\right)_{3}>5 \mathrm{Ni}-$ $3 \mathrm{La}_{2} \mathrm{O}_{3} @ \mathrm{Al}_{2}\left(\mathrm{SiO}_{2}\right)_{3}>\mathrm{Al}_{2}\left(\mathrm{SiO}_{2}\right)_{3}$. Note that, with the last two catalysts acetic acid conversion of $88 \%$ and $71 \%$ were achieved, respectively.

$5 \mathrm{Ni}-3 \mathrm{La}_{2} \mathrm{O}_{3} @ \mathrm{Al}_{2}\left(\mathrm{SiO}_{2}\right)_{3}$ and $\mathrm{Al}_{2}\left(\mathrm{SiO}_{2}\right)_{3}$ catalysts showed quite stable activity over 3 hours of reaction period. Additionally, bi- metallic $5 \mathrm{Ni}-3 \mathrm{CaO} @ \mathrm{Al}_{2}\left(\mathrm{SiO}_{2}\right)_{3}$ and $5 \mathrm{Ni}-3 \mathrm{MgO} @ \mathrm{Al}_{2}\left(\mathrm{SiO}_{2}\right)_{3}$ catalysts were stable at the beginning of the experiment; however, suddenly at the $90^{\text {th }}$ minutes, their selectivity values started decreasing noticeably. A catalyst deactivation process occurred. This result can be explained by the blockage of the active sides of pores of these catalysts.

Gaseous products distribution of the prepared metal based $\mathrm{Al}_{2}\left(\mathrm{SiO}_{2}\right)_{3}$ supported catalysts are given in Figure 7. As can be seen from Figure 7, while the highest amount of $\mathrm{CO}_{2}$ was obtained over the pure catalyst support, the highest proportion of $\mathrm{CO}$ was recorded over the $\mathrm{Ni}$-containing La promoted $5 \mathrm{Ni}$ - 
$3 \mathrm{La}_{2} \mathrm{O}_{3} @ \mathrm{Al}_{2}\left(\mathrm{SiO}_{2}\right)_{3}$ catalyst. Additionally, Ce promoted catalyst exhibit the best hydrogen yield of $43 \%$ compared to the other catalyst.

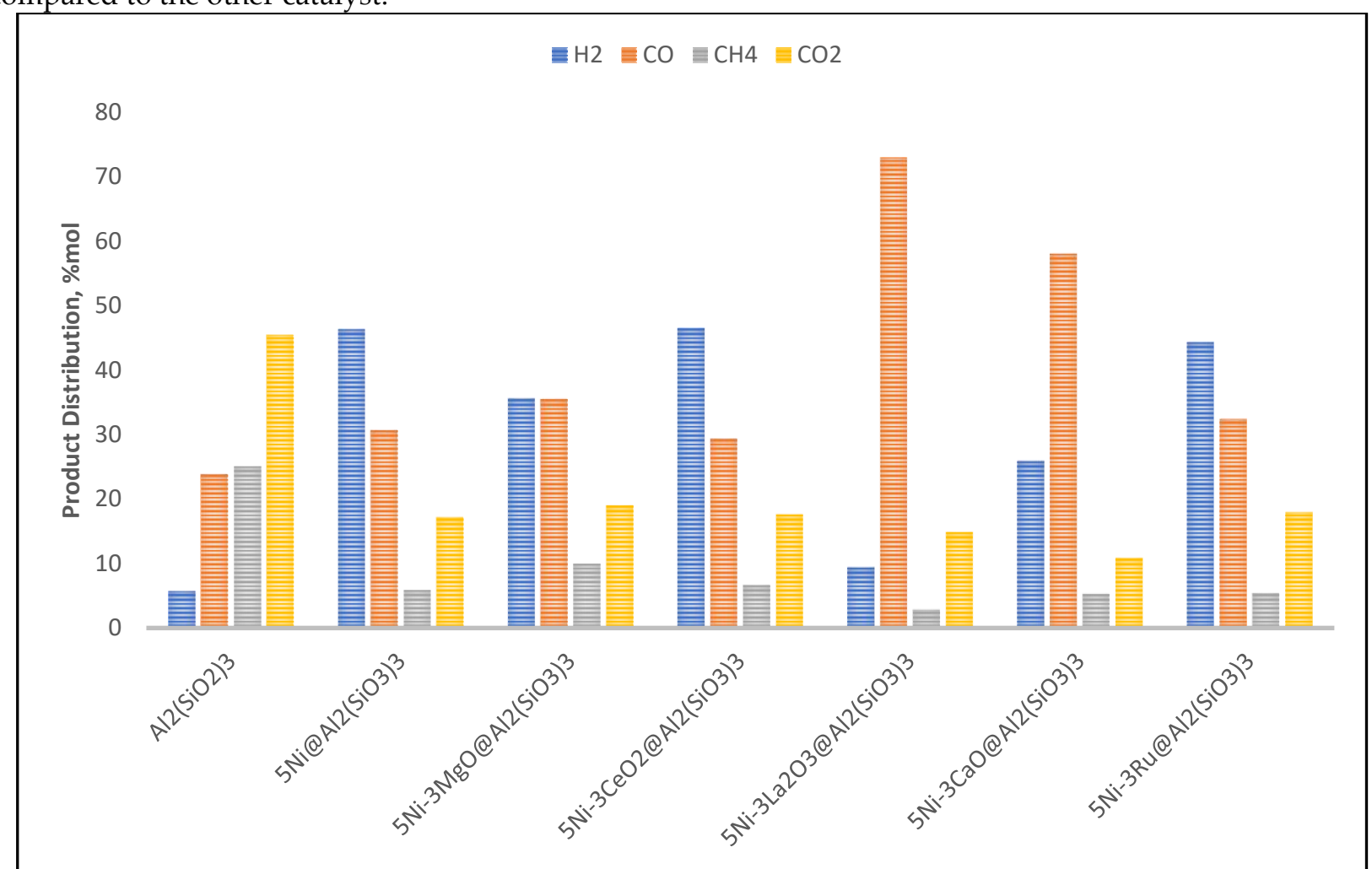

Figure 7. Gaseous products distribution of the synthesized catalysts

\subsection{Coke formation}

Thermogravimetric (TG) measurement was recorded from $25 \mathrm{C}$ to $950 \mathrm{C}$ to determine the type and the amount of carbon formed and heat evolved of the spent metal-containing catalysts is given in Figure 8. As seen from Figure 8, the initial weight reduction, up to $400 \mathrm{C}$, stem from the thermal desorption of water, volatile compounds as well as carbon dioxide removal. 

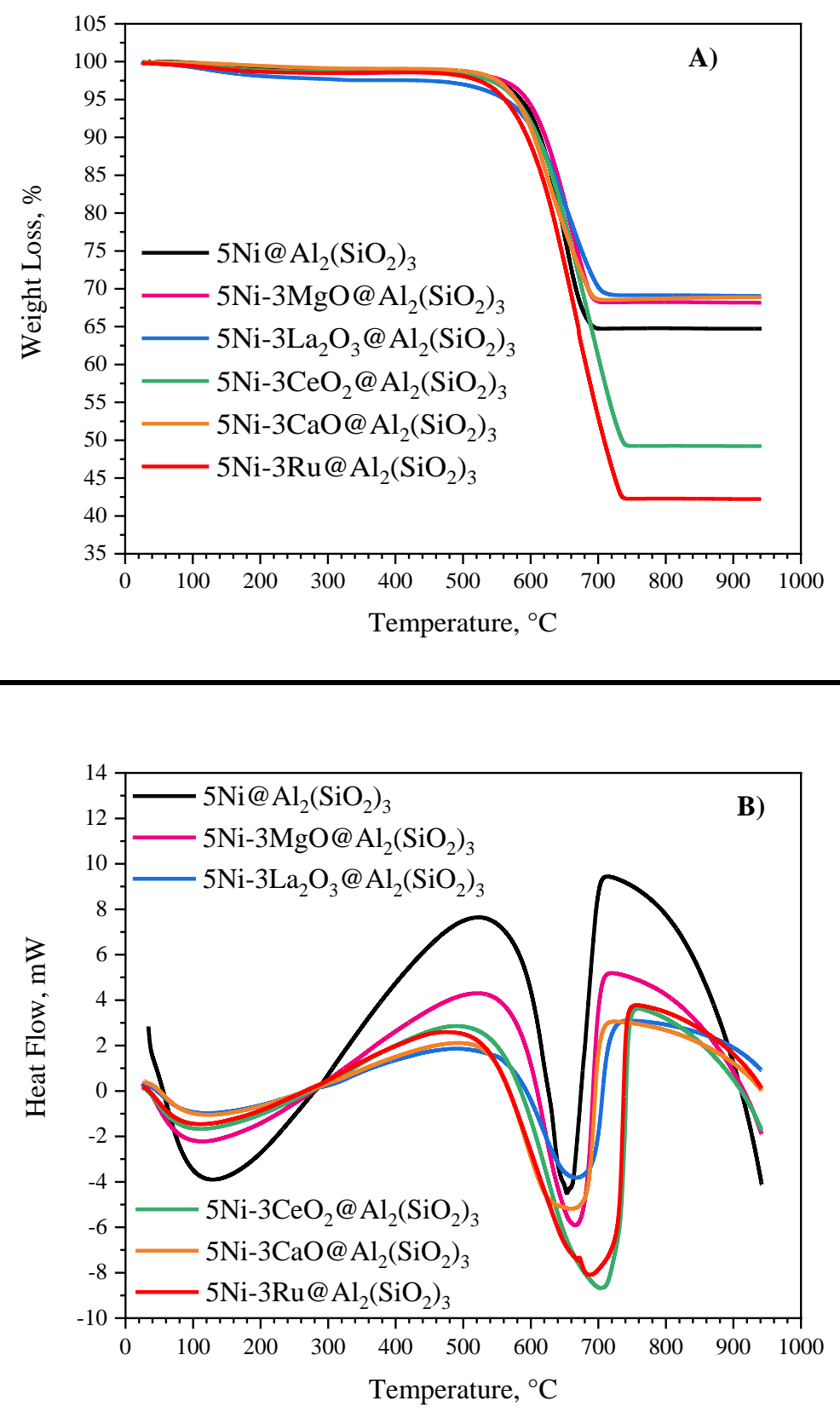

Figure 8. A) TGA and B) DTA profiles of the spent catalysts

Besides, the significant weight loss observed between $600 \mathrm{C}$ and $800 \mathrm{C}$ is due to the formation of carbon species on the surface of the catalysts which cause their deactivation. Despite the acceptable activity test performance exhibited by the mono-metallic $5 \mathrm{Ni} @ \mathrm{Al}_{2}\left(\mathrm{SiO}_{2}\right)_{3}$ catalyst, the highest amount of coke of approximately $33.75 \%$ by weight was deposited on the surface of this catalyst due to its high surface acidity (Arbag et al., 2018).

Furthermore, the incorporation of La species in the mono-metallic catalyst played a remarkable role by reducing the percentage of carbon formed from $33.75 \%$ to $28.3 \%$ by weight. The highest amount of carbon 
(56.3\%) was recorded over the $5 \mathrm{Ni}-3 \mathrm{Ru} @ \mathrm{Al}_{2}\left(\mathrm{SiO}_{2}\right)_{3}$ catalyst. Besides, quite high coke content of $49.4 \%$ was determined on the surface of the $5 \mathrm{Ni}-3 \mathrm{CeO}_{2} @ \mathrm{Al}_{2}\left(\mathrm{SiO}_{2}\right)_{3}$ catalyst. However, slightly similar and lower carbon content were measured over the $5 \mathrm{Ni}-3 \mathrm{La}_{2} \mathrm{O}_{3} @ \mathrm{Al}_{2}\left(\mathrm{SiO}_{2}\right)_{3}(28.3 \%), 5 \mathrm{Ni}-3 \mathrm{CaO} @ \mathrm{Al}_{2}\left(\mathrm{SiO}_{2}\right)_{3}(29.7 \%)$ and $5 \mathrm{Ni}-$ $3 \mathrm{MgO} @ \mathrm{Al}_{2}\left(\mathrm{SiO}_{2}\right)_{3}(29.8 \%)$ catalysts.

Differential thermal analysis (DTA) profiles of the spent catalysts are shown in Figure 8B. It was reported that three main types of carbon species such as amorphous carbon, filament carbon and graphite carbon can be seen during thermogravimetric and differential measurements, which occur below $450 \mathrm{C}$, between 450-750 C, and above 750 C, respectively (Fautex-Lefebvre et al., 2010; Pu et al., 2018). In Figure 8B, weak and strong exothermic peaks were observed at around $600 \mathrm{C}$ and $700 \mathrm{C}$, in turn. This result confirms the formation of only filament carbon over all the catalysts' surfaces.

\section{CONCLUSION}

The main purpose of this study was to examine the influence of incorporation of basic promotors to the commercial $\mathrm{Al}_{2}\left(\mathrm{SiO}_{2}\right)_{3}$ catalyst support for Ni-based catalysts. A wet impregnation method was used to prepare the metal-containing catalysts. XRD results confirmed the successful development of catalysts. The bare aluminosilicate $\left(\mathrm{Al}_{2}\left(\mathrm{SiO}_{2}\right)_{3}\right)$ catalyst support exhibited a surface area of $58.55 \mathrm{~m}^{2} / \mathrm{g}$ and a large pore diameter of $3.35 \mathrm{~nm}$. However, Ni impregnation reduces the surface areas and average pore volumes of the catalysts. This is due to the partial blockage of the support pores by NiO clusters or the partial collapse of the pore structures. The catalytic activity results revealed, acetic acid conversion value of $79 \%$ was obtained with $5 \mathrm{Ni}-3 \mathrm{CeO}_{2} @ \mathrm{Al}_{2}\left(\mathrm{SiO}_{2}\right)_{3}$ catalyst, indicating that this catalyst was very active in the conversion of acetic acid to hydrogen-rich $\left(\mathrm{H}_{2} / \mathrm{CO}=1.58\right)$ gas. However, syngas $\left(\mathrm{H}_{2}+\mathrm{CO}\right)$ with equimolar proportion (about $35.58 \%$ and $35.49 \%$, respectively) is produced over the $5 \mathrm{Ni}-3 \mathrm{MgO} @ \mathrm{Al}_{2}\left(\mathrm{SiO}_{2}\right)_{3}$ catalyst. Thermogravimetric and differential thermal analysis showed that $5 \mathrm{Ni}-3 \mathrm{La}_{2} \mathrm{O}_{3} @ \mathrm{Al}_{2}\left(\mathrm{SiO}_{2}\right)_{3}, 5 \mathrm{Ni}-3 \mathrm{CaO} @ \mathrm{Al}_{2}\left(\mathrm{SiO}_{2}\right)_{3}$ and $5 \mathrm{Ni}-3 \mathrm{MgO} @ \mathrm{Al}_{2}\left(\mathrm{SiO}_{2}\right)_{3}$ catalysts were resistant to carbon formation compared to $5 \mathrm{Ni} @ \mathrm{Al}_{2}\left(\mathrm{SiO}_{2}\right)_{3}, 5 \mathrm{Ni}-3 \mathrm{CeO}_{2} @ \mathrm{Al}_{2}\left(\mathrm{SiO}_{2}\right)_{3}$ and $5 \mathrm{Ni}$ $3 \mathrm{Ru} @ \mathrm{Al}_{2}\left(\mathrm{SiO}_{2}\right)_{3}$ catalysts. Hence $\mathrm{La}_{2} \mathrm{O}_{3}, \mathrm{CaO}$ and $\mathrm{MgO}$ incorporation played an important role in reducing coke deposition and improving catalysts stability.

\section{ACKNOWLEDGE}

The authors are grateful for the financial support provided by Gazi University Scientific Research Fund under the Research Project of FGA-2021-7076.

\section{REFERENCES}

Arbag, H. 2018, “Effect of impregnation sequence of Mg on performance of mesoporous alumina supported Ni catalyst in dry reforming of methane", International Journal of Hydrogen Energy, 43, 6561-6574.

An, L., Dong, C., Yang, Y., Zhang, J., \& He, L. 2011, “The influence of Ni loading on coke formation in steam reforming of acetic acid. Renewable Energy, 36, 930-935.

Basile, A., Gallucci, F., Iulianelli, A., Borgognoni, F., Tosti, S. 2008, "Acetic acid steam reforming in a Pd-Ag membrane reactor: the effect of the catalytic bed pattern", Journal of Membrane Science, 311, 46-52.

Basagiannis, A. C., Verykios, X. E. 2007, "Catalytic steam reforming of acetic acid for hydrogen production", International journal of hydrogen energy, 32, 3343-3355.

Cakiryilmaz, N., Arbag, H., Oktar, N., Dogu, G., Dogu, T. 2018, “Effect of W incorporation on the product distribution in steam reforming of bio-oil derived acetic acid over $\mathrm{Ni}$ based Zr-SBA-15 catalyst", International Journal of Hydrogen Energy, 43, 3629-3642. 
Chen, B., Lin, J., Chen, X., Zheng, Y., Zhang, H., Huang, F., ... Zheng, Y. 2020, “Controllable synthesis of mesoporous alumina as support for palladium catalysts and reconstruction of active sites during methane combustion", International Journal of Hydrogen Energy, 45, 15142-15156.

Chen, G., Tao, J., Liu, C., Yan, B., Li, W., \& Li, X. 2017, “Hydrogen production via acetic acid steam reforming: a critical review on catalysts", Renewable and Sustainable Energy Reviews, 79, 1091-1098.

Chen, J., Wang, M., Wang, S., \& Li, X. 2018, “Hydrogen production via steam reforming of acetic acid over biochar-supported nickel catalysts", International Journal of Hydrogen Energy, 43, 18160-18168.

Choi, I.H., Hwang, K.R., Lee, K.Y. and Lee, I.G., 2019, "Catalytic steam reforming of biomass-derived acetic acid over modified $\mathrm{Ni} / \gamma$-A12O3 for sustainable hydrogen production", International Journal of Hydrogen Energy, 44, 180-190.

Chong, C.C., Teh, L.P. and Setiabudi, H.D., 2019, "Syngas production via CO2 reforming of CH4 over Nibased SBA-15: Promotional effect of promoters (Ce, Mg, and Zr)", Materials Today Energy, 12, 408-417.

Fauteux-Lefebvre, C., Abatzoglou, N., Blanchard, J. and Gitzhofer, F., 2010, "Steam reforming of liquid hydrocarbons over a nickel-alumina spinel catalyst", Journal of Power Sources, 195, 3275-3283.

Fu, P., Zhang, A., Luo, S., Yi, W., Hu, S. and Zhang, Y., 2019, “Catalytic steam reforming of biomass-derived acetic acid over two supported Ni catalysts for hydrogen-rich syngas production", ACS omega, 4, 13585-13593.

Goicoechea, S., Ehrich, H., Arias, P. L., \& Kockmann, N. 2015, “Thermodynamic analysis of acetic acid steam reforming for hydrogen production", Journal of power sources, 279, 312-322.

Guggilla, V.S., Akyurtlu, J., Akyurtlu, A. and Blankson, I., 2010, "Steam reforming of n-dodecane over RuNi-based catalysts", Industrial \& Engineering Chemistry Research, 49, 8164-8173.

Hu, X., Dong, D., Shao, X., Zhang, L. and Lu, G., 2017, "Steam reforming of acetic acid over cobalt catalysts: Effects of Zr, Mg and K addition", International Journal of Hydrogen Energy, 42, 4793-4803.

Karaman, B. P., Cakiryilmaz, N., Arbag, H., Oktar, N., Dogu, G., Dogu, T. 2017, “Performance comparison of mesoporous alumina supported $\mathrm{Cu} \& \mathrm{Ni}$ based catalysts in acetic acid reforming. International Journal of Hydrogen Energy", 42, 26257-26269.

Morris, S. M., Fulvio, P. F., Jaroniec, M. 2008, “Ordered mesoporous alumina-supported metal oxides”, Journal of the American Chemical Society, 130, 15210-15216.

Murata, K., Wang, L., Saito, M., Inaba, M., Takahara, I. and Mimura, N., 2004, "Hydrogen production from steam reforming of hydrocarbons over alkaline-earth metal-modified Fe-or Ni-based catalysts", Energy \& fuels, 18, 122-126.

Nabgan, W., Abdullah, T. A. T., Mat, R., Nabgan, B., Gambo, Y., Moghadamian, K. 2016, “Acetic acid-phenol steam reforming for hydrogen production: Effect of different composition of La2O3-Al2O3 support for bimetallic Ni-Co catalyst", Journal of environmental chemical engineering, 4, 2765-2773.

Nabgan, W., Abdullah, T.A.T., Mat, R., Nabgan, B., Jalil, A.A., Firmansyah, L. and Triwahyono, S., 2017, "Production of hydrogen via steam reforming of acetic acid over $\mathrm{Ni}$ and Co supported on La2O3 catalyst", international journal of hydrogen energy, 42, 8975-8985.

Omoregbe, O., Danh, H.T., Abidin, S.Z., Setiabudi, H.D., Abdullah, B., Vu, K.B. and Vo, D.V.N., 2016, "Influence of lanthanide promoters on Ni/SBA-15 catalysts for syngas production by methane dry reforming", Procedia engineering, 148, 1388-1395.

Omoregbe, O., Danh, H.T., Nguyen-Huy, C., Setiabudi, H.D., Abidin, S.Z., Truong, Q.D. and Vo, D.V.N., 2017, "Syngas production from methane dry reforming over Ni/SBA-15 catalyst: Effect of operating parameters", international journal of hydrogen energy, 42, 11283-11294.

Ozel, S., Meric, G. G., Arbag, H., Degirmenci, L., \& Oktar, N. 2020, "Steam reforming of acetic acid in the presence of $\mathrm{Ni}$ coated with $\mathrm{SiO} 2$ microsphere catalysts", International Journal of Hydrogen Energy, 45, 21252-21261.

UKMK2020: 14. Ulusal Kimya Mühendisliği Kongresi'nde sunulan bildiriler arasından seçilmiştir. (10-12 Haziran 2021 Konya, TÜRKIYYE) 
Phung, T.K., Pham, T.L.M., Nguyen, A.N.T., Vu, K.B., Giang, H.N., Nguyen, T.A., Huynh, T.C. and Pham, H.D., $\quad 2020$, "Effect of supports and promoters on the performance of Ni-based catalysts in ethanol steam reforming", Chemical Engineering \& Technology, 43, 672-688.

Pu, J., Luo, Y., Wang, N., Bao, H., Wang, X. and Qian, E.W., 2018, “Ceria-promoted Ni@ Al2O3 core-shell catalyst for steam reforming of acetic acid with enhanced activity and coke resistance", International Journal of Hydrogen Energy, 43, 3142-3153.

Rodrigues, C. T., Alonso, C. G., Machado, G. D., de Souza, T. L. 2020, “Optimization of bio-oil steam reforming process by thermodynamic analysis", International Journal of Hydrogen Energy, 45, 28350-28360.

Sahin, S. O., Arbag, H., Oktar, N., Murtezaoglu, K. 2019, “Catalytic Performances of Bi-Metallic Ni-Co Catalysts in Acetic Acid Steam Reforming Reaction: Effect of Mg Incorporation", International Journal of Chemical Reactor Engineering, 17.

Thangadurai, T. and Tye, C.T., 2021, "Acidity and basicity of metal oxide-based catalysts in catalytic cracking of vegetable oil", Brazilian Journal of Chemical Engineering, 1-20.

Yang, X., Wang, Y., Li, M., Sun, B., Li, Y. and Wang, Y., 2016, "Enhanced hydrogen production by steam reforming of acetic acid over a Ni catalyst supported on mesoporous $\mathrm{MgO}^{\prime \prime}$, Energy \& Fuels, 30, 21982203.

Wang, S., Zhang, F., Cai, Q., Zhu, L., \& Luo, Z. 2015, “Steam reforming of acetic acid over coal ash supported Fe and Ni catalysts", International Journal of Hydrogen Energy, 40, 11406-11413.

Wang, M., Zhang, F. and Wang, S., 2017, “Effect of La2O3 replacement on $\gamma$-A12O3 supported nickel catalysts for acetic acid steam reforming", International Journal of Hydrogen Energy, 42, 20540-20548.

Zdravkov, B., Čermák, J., Šefara, M., Janků, J. 2007, “Pore classification in the characterization of porous materials: A perspective", Open Chemistry, 5, 385-395.

Zhang, Z., Hu, X., Gao, G., Wei, T., Dong, D., Wang, Y., Geng, D. 2019, “Steam reforming of acetic acid over $\mathrm{NiKOH} / \mathrm{Al} 2 \mathrm{O} 3$ catalyst with low nickel loading: The remarkable promotional effects of $\mathrm{KOH}$ on activity", International Journal of Hydrogen Energy, 44, 729-747.

Zhang, Z., Hu, X., Li, J., Gao, G., Dong, D., Westerhof, R., Wang, Y. 2018, “Steam reforming of acetic acid over $\mathrm{Ni} / \mathrm{Al} 2 \mathrm{O} 3$ catalysts: Correlation of nickel loading with properties and catalytic behaviors of the catalysts", Fuel, 217, 389-403.

Zhang, C., Hu, X., Yu, Z., Zhang, Z., Chen, G., Li, C., Liu, Q., Xiang, J., Wang, Y. and Hu, S., 2019, “Steam reforming of acetic acid for hydrogen production over attapulgite and alumina supported $\mathrm{Ni}$ catalysts: impacts of properties of supports on catalytic behaviors", International Journal of Hydrogen Energy, 44, 5230-5244.

Zhang, F., Wang, N., Yang, L., Li, M. and Huang, L., 2014, "Ni-Co bimetallic MgO-based catalysts for hydrogen production via steam reforming of acetic acid from bio-oil", international journal of hydrogen energy, 39, 18688-18694. 